\title{
Synthetic Peptide Synthesis
}

National Cancer Institute

\section{Source}

National Cancer Institute. Synthetic Peptide Synthesis. NCI Thesaurus. Code C113075.

The process of producing peptides by the polymerization of amino acids. 